\title{
7 INNISH EFFORTS TO PROMOTE CULTURAL RELATIONS WITH ROMANIA DURING THE SECOND WORLD WAR
}

\section{Kari Alenius}

University of Oulu, E-mail: kari.alenius@oulu.fi

\section{Acknowledgements}

This paper is based on the presentation made at the Fifth international conference on Baltic and Nordic Studies in Romania A piece of culture, a culture of peace, re-imaging European communities in the North Sea, Baltic Sea and Black Sea regions, hosted by Valahia University of Târgovişte and the Romanian Association for Baltic and Nordic Studies, August 17-19, 2014. Supported by EEA Grants, contract no 4/22.07.2014.

\begin{abstract}
:
This paper analyzes intercultural relations between Finland and Romania during the Second World War. The main focus is on the Finnish viewpoints. The aim of the analysis is to explain why the Finnish activities at this field of life were of a certain kind.Intercultural relations between Finland and Romania do not form a separate field of study, but are closely intertwined with the two countries' mutual relationship on the whole. At the same time, this interrelation was dependent on the overall situation in World War II, with its shifting strategies.

Existing Finnish archive material on cultural cooperation clearly indicates that, in terms of advancing this relationship, Romania was clearly the more active party throughout. In Finland, the group of activists favouring Romania was smaller and more heterogeneous, and the government's stance in particular was hesitant. The explanation for this Finnish restraint lies in Finland's special relationship with Hungary.The Finns hesitated to implement Romanian initiatives in the field of culture, fearing that they would jeopardise relations with Hungary.

Despite the Finnish government's hesitation regarding the development of cultural relations with Romania, there were also advocates of closer cultural ties. A key figure in the Ministry of Foreign Affairs was envoy Eduard Hjalmar Palin. Another significant player was the FinnishRomanian Association, which commenced activities in January 1943 and continued until the summer of 1944 .
\end{abstract}

\section{Rezumat:}

Acest articol analizează relațiile interculturale dintre Finlanda și România din timpul celui deAl Doilea Război Mondial. Punctul central îl reprezintă punctele de vedere finlandeze. Scopul analizei este acela de a explica de ce activitățile finlandeze din acest areal au fost de un anumit tip. Relațiile interculturale dintre Finlanda și România nu formează o arie separată de studiu, ci sunt legate indisolubil de relațiile reciproce dintre cele două state în ansamblul lor. 
Materialul de arhivă finlandez existent, care abordează cooperarea culturală, indică foarte clar faptul că, în ceea ce privește avansul acestei relații, România a reprezentat partea mai activă pe tot parcursul lor. In Finlanda, grupul de activiști care favorizau România era mai mic și mai eterogen, iar atitudinea guvernului era ezitantă. Explicația acestei reticențe o constituie relația specială a acestui stat cu Ungaria. Finlandezii au ezitat să implementeze inițiativele românești din domeniul culturii, temându-se că ar putea pune în pericol relația cu Ungaria.

In ciuda nehotărârii guvernului finlandez în ceea ce privește dezvoltarea relațiilor culturale cu România, au existat apărători ai unor legături mai apropiate. O figură centrală în Ministerul Afacerilor Externe a fost agentul diplomatic Eduard Hjalmar Palin. Un alt actor important a fost, de asemenea, Asociația Finlandezo-Română, care și-a început activitatea în ianuarie 1943 și a continuat-o până în vara anului 1944.

Keywords: Romania, Finland, cultural relations, foreign policy, Second World War, Finnish-Romanian Association

\section{Introduction}

During the Second World War, Finland and Romania shared a number of common interests and fought on the Axis side from 1941 to 1944, although without an official mutual alliance agreement. Nevertheless, co-belligerency of this kind made Finland and Romania more important to each other than ever before or since. The situation also created favourable conditions for the furthering of cultural relations between the two countries in principle. ${ }^{1}$

Wartime cultural relations between Finland and Romania have been studied to a reasonable extent. Studies exist that are primarily based on Romanian materials and which focus on the Romanian point of view and activities. Silviu Miloiu has published several articles dealing with or touching on this subject. The most significant of these is "Cultures at war: The cultural relations between Romania and Finland during the Second World War", which was published in 2005.2Another work worth mentioning is Erkki Salo's Finnish-language "Kulttuurikomennus. Suomalais-romanialainen yhdistys 1943-1944", a survey that gives an overview of the Finnish-Romanian Association. ${ }^{3}$ The association played, as far as semi-official relations with Romania were concerned, a remarkable role in Finland. On the other

\footnotetext{
${ }^{1}$ Compare with Silviu Miloiu, "From "allies without alliance" to concerted action: Romania and Finland in the aftermath of the Operation Barbarossa (1941), in Revista Română de Studii Baltice şi Nordice, Vol. 2, Nr. 2 (2010), 249-284.

2 Silviu Miloiu, "Cultures at war: The cultural relations between Romania and Finland during the Second World War", in Anuarul Institutului de Istorie "A. D. Xenopol", t. XLII, 2005, 409-421 (hereafter cited as Miloiu 2005a). See also Silviu Miloiu, "Mobilizing the European idea at Europe's eastern frontier. The war propaganda of Romania and Finland as recorded in their bilateral relationship", in Valahian Journal of Historical Studies, 3-4/2005, 67-75; Silviu Miloiu, "Finnish views and political attitudes concerning the Romanian-Hungarian clash over Transylvania (1941-1942), in Studia Universitatis Babeş-Bolyai, Studia Europaea, LI, 1, 2006, 105-119; Silviu Miloiu, "Diverging their destinies. Romania, Finland and the September 1944 armistices", in Valahian Journal of Historical Studies, 10/2008, 41-55.
}

${ }^{3}$ Erkki Salo, Kulttuurikomennus. Suomalais-romanialainen yhdistys 1943-1944 (Helsinki: Albion, 2013). 
hand, much less attention has been paid to the role and activities of Finnish authorities and the Finnish media in this respect.

This study aims to complement the picture with a systematic analysis of Finnish archive materials, above all those of the Finnish Ministry of Foreign Affairs and the Finnish Embassy in Bucharest. The study focuses on Finnish authorities and leading Finnish newspapers, but also takes account of the work of the FinnishRomanian Association, thus aiming at a better understanding of the mutual interaction between the Finnish parties concerned.

Intercultural relations between Finland and Romania do not form a separate field of study, but are closely intertwined with the two countries' mutual relationship on the whole. At the same time, this interrelation was dependent on the overall situation in World War II, with its shifting strategies. Before the Second World War, interaction between Finland and Romania was minimal. In 1923, for instance, Finland closed its embassy in Bucharest after only two years. The reasons for the discontinuation were financial, and the embassy would not be re-established until 1939.4 This episode shows that Romania was not considered particularly important in the 1920s and 1930s.

The outbreak of the Second World War marked a turning point in the relationship. The Winter War was followed closely by many Romanians, an interest which continued during 1940-1944..$^{5}$ Finland and Romania had almost identical positions as neighbours of the Soviet Union. Both fell victim to Soviet aggression and the politics of conquest in the early stages of the war, which caused both to turn to Germany for safety, and to join the war on the German side from the summer of 1941 onwards. Finland and Romania had very similar interests regarding the war and the ensuing peace treaties, regardless of which of the main antagonists would win.

The consensus in Romania viewed Finland as a natural ally for the reasons stated above. ${ }^{6}$ Not only did the two countries share an interest in eliminating the threat posed by the Soviet Union, but both also had to ensure that Germany did not become too dominant a partner. Cooperation between the two small countries facilitated the striking of a balance in this regard. Furthermore, Romania was in need of support in its efforts to revoke the border treaties of 1940, which had ceded

\footnotetext{
4Silviu Miloiu, "An untold story: The Romanian-Finnish diplomatic bonds (1923-1939)", in Valahian Journal of Historical Studies, 7-8/2007, 108-109; Jukka Nevakivi, Ulkoasiainhallinnon historia 1918-1956 (Helsinki: Ulkoasiainministeriö, 1988), 70.

${ }^{5}$ Lauri Lindgren, "Suomalaisten ja romanialaisten kontaktit menneinä aikoina", in 80 vuotta Suomen ja Romanian välisiä diplomaattisuhteita (Helsinki: Embassy of Romania, National Archives of Finland \& Finnish-Romanian Friendship Association, 2000), 22; Miloiu 2005a, 410-411.

6 Miloiu 2005a, 411-412; Otto Rintala, ""Erillissodan maat" Suomi ja Romania toisessa maailmansodassa Suomen Bukarestin-lähetystön toiminnan näkökulmasta", in Ajankohta 2007. Poliittisen historian vuosikirja. Toim. Klaus Lindgren (Helsinki: Helsingin yliopisto \& Turun yliopisto, 2007), 215-219.
} 
a large part of Transylvania to Hungary. It aimed to convince Finland, alongside many other states, to side with Romania in the Transylvania dispute. ${ }^{7}$

Romania worked hard on consolidating its relationship with Finland during 1941-1944. While politics clearly took precedence in these efforts, cultural interaction was considered an important means of supporting the greater political aims in question. ${ }^{8}$ It is likely that a similar supporting role was assigned to bilateral economic relations, too. Existing Finnish archive material on cultural cooperation clearly indicates (as will be discussed more in detail below) that, in terms of advancing this relationship, Romania was clearly the more active party throughout. The Romanian government showered Finland with attention and openly expressed its wish to expand and intensify interaction. In Finland, the group of activists favouring Romania was smaller and more heterogeneous, and the government's stance in particular was hesitant. Romanian initiatives were met with an outwardly polite response among Finnish officials but were advanced with caution. Actions were often delayed, and counter-proposals were made slowly, if at all.

\section{The Finnish restraint}

What is the explanation for this Finnish restraint, given that the alignment of interests concerning major strategic issues, i.e. relations with the Soviet Union and Germany, must have been apparent to the Finns as well? The answer lies in Finland's special relationship with Hungary. As a result of the ethnic ideology prevalent in Finland at the time, there was a strong tendency among Finns to consider the Hungarian people as kinfolk and close friends, and to view e.g. the Transylvanian question and the Trianon peace treaty from a Hungarian nationalist perspective. Between the wars, the friendship between Finland and Hungary had been fostered by schools and the media alike, and the situation in Hungary was similar. ${ }^{9}$

Documents archived by the Finnish Ministry of Foreign Affairs prove that, time after time, Finns hesitated to implement Romanian initiatives in the field of culture, fearing that they would jeopardise relations with Hungary. The most obvious example is the fate of the bilateral cultural agreement suggested by Romania. Following the ratification of such agreements with Croatia and Slovakia, Romania made a corresponding proposal to Finland in the spring of 1942.10 Finland had previously signed cultural agreements with its "kinspeople", i.e. Estonia and

\footnotetext{
7 Miloiu 2006, 105-108; Rintala 2007, 219.

8 Compare with Miloiu 2005, 411-412, 421.

9 Anssi Halmesvirta, Rakkaat heimoveljet: Unkari ja Suomi 1920-1945 (Jyväskylä: Historietti Oy, 2010), 8-14; Anu Kukkonen, Pustalla ei ole polkua. Unkari-kuva äidinkielen oppikirjoissa (unpublished M.A. thesis; Jyväskylä: Jyväskylän yliopisto, 2003), 24-50.

10Ministry of Foreign Affairs to Finnish Legation in Bucharest, 17 December 1942. Archives of the Finnish Legation in Bucharest (hereafter AFLB), I E 2a.
} 
Hungary, in 1937.11 The Romanian initiative was weighed up by the Ministry of Education during 1942, and a cautiously positive statement was issued by the end of the year. However, the Ministry of Foreign Affairs was more suspicious. As a prerequisite for approval, the Ministry demanded that the agreement be much more limited than those entered into with Estonia and Hungary and that it be kept to a very general level. ${ }^{12}$

The Finnish response was submitted to Romania in late December of 1942. The Finnish envoy in Bucharest, Eduard Hjalmar Palin, regarded the stripped-down proposal as an insult to Romania, but still used it as the basis for negotiations in Bucharest at the beginning of the following year. ${ }^{13}$ By the end of January 1943, Romania had announced that it was ready, in principle, to accept the agreement on Finnish terms. ${ }^{14}$ Nevertheless, the Finnish Ministry of Foreign Affairs continued to delay the matter. When the legation in Bucharest inquired about the state of affairs in April, the answer was that "Foreign Minister Ramsay doesn't seem to be particularly interested at the moment, although the matter is, of course, still pending and under preparation". ${ }^{15}$ In other words, Finland did not officially want to terminate the negotiations - which would have caused a diplomatic scandal but internal correspondence between Finnish authorities makes it clear that Finland did not want the agreement. The draft of the agreement was still "pending and under preparation" by the end of the war, and was never signed.

The Ministry of Foreign Affairs' archives reveal that, throughout the agreement process, numerous Finnish officials feared that closer relations with Romania would damage the relationship between Finland and Hungary. ${ }^{16}$ It is in fact true that the Hungarian legation in Helsinki was watching the development of the Finnish-Romanian relationships with concern. Romania's active efforts to promote its culture in Finland, as well as the large number of visits from Romania, raised fears that the Finns might gain too positive an image of the country. This in turn might weaken Finnish sympathies for Hungary and increase understanding for the Romanian point of view, with regard to the Romanian-Hungarian disputes. Hungary and its Finnish friends therefore tried their best to prevent cultural interaction between Romania and Finland. The Finnish-Hungarian Association, for

\footnotetext{
11 Ministry of Education and Culture: Cultural Agreements. Http://www.minedu.fi/OPM/Kansainvaeliset_asiat/kulttuurisopimukset_ja_ohjelmat/?lang=en (accessed 5 August 2014).

${ }_{12}^{12}$ Ministry of Foreign Affairs to Finnish Legation in Bucharest, 17 December 1942. AFLB, I E 2a.

13Palin to Minister Asko Ivalo, 28 December 1942. AFLB, I E 2a.

14 Palin to Ministry of Foreign Affairs, 25 January 1943, AFLB, I E 2a.

${ }^{15}$ Secretary of Legation Soini Palaste to Ministry of Foreign Affairs, 12 April 1943; Ministry of Foreign Affairs to Palasto, 4 May 1943, AFLB, I E 2a.

${ }_{16}$ Ministry of Foreign Affairs to Finnish envoy in Budapest, 17 December 1942; Ministry of Foreign Affairs to Finnish Legation in Bucharest, 17 December 1942; Palin to Minister Asko Ivalo, 28 December 1942, AFLB, I E 2a.
} 
example, forbade its members from taking any involvement in the FinnishRomanian Association. ${ }^{17}$

Envoy Palin also had a long-lasting dispute with his colleague - Finnish envoy Aarne Wuorimaa in Bucharest - over the Transylvanian question and the "correct" emphasis of the Finnish relations with Romania and Hungary. While Wuorimaa found that Hungary should remain in the prime position, Palin spoke for a more balanced situation. ${ }^{18}$

From spring 1943 on, the hesitancy displayed by Foreign Minister Ramsay and the Finnish government was corroborated by the changed strategic situation in the World War. Germany's defeat began to seem likely in early 1943 and Finland was beginning to seek ways of disengaging itself from the war before the situation became catastrophic. Any official intensification of the ties with Germany's other allies, such as Romania, was risky under these circumstances. Instead, the advisable course of action was to distance oneself from these former brothers in arms and try to establish contacts with the Western allies. One indication of Finland's revised approach was the change of government in March 1943. The above-mentioned Ramsay, who replaced the German-minded Rolf Witting, had Scottish roots and was known for his sympathies towards Britain and the Anglo-American culture. ${ }^{19}$

\section{Advocates of closer cultural ties}

Despite the Finnish government's hesitation regarding the development of cultural relations with Romania and the straightforwardly negative or even hostile attitude of Finnish proponents of the kinship ideology, there were also advocates of closer cultural ties. A key figure in the Ministry of Foreign Affairs was envoy Palin who, during his tenure in Bucharest from spring 1941 to autumn 1944, worked hard to improve the attitude of the Finnish government and the Ministry of Foreign Affairs towards Romania. In dozens of reports and letters, Palin explained why relations with Romania should be intensified and how to best achieve this. ${ }^{20 \mathrm{He}}$ strongly advocated and expressed his personal understanding of the Romanian point of view. At times, Palin seemed to be downright frustrated at Finland's

\footnotetext{
17Halmesvirta 2010, 164-165.

18 Miloiu 2006, 110-119. For Palin's arguments, see in particular, Palin's reports to Ministry of Foreign Affairs, 9 September 1942, 19 November 1942. Archives of the Finnish Ministry of Foreign Affairs (hereafter AFMFA), 5 C 14.

${ }^{19}$ Erkki Maasalo, Sir Henrik saa tehtävän. Henrik Ramsayn ulkoasiainministerikausi 1943-1944 (Espoo: Fenix-Kustannus Oy, 2004), 124-125; Nevakivi 1988, 215-216.

20See, for instance, Palin's report to Ministry of Foreign Affairs, 4 February 1942, AFMFA, 5 C 14; Palin's report to Ministry of Foreign Affairs, 5 March 1943, AFLB, I E 2b; Palin to Ministry of Foreign Affairs, 17 March 1943, AFLB, I D 1b; Palin to Ministry of Foreign Affairs, 12 April 1943, AFLB, I E 2; Palin's annual reports to Ministry of Foreign Affairs 1941-1944, AFLB, III A 2. See also Kari Alenius, ""An Excellent Friend Afflicted with Internal Difficulties": The Image of Romania Conveyed by the Finnish Embassy in Bucharest, 1939-1945", in Valahian Journal of Historical Studies, 16/2011, 26-33.
} 
inability to offer an appropriate response to Romania's initiatives and offers of friendship. Among other issues, he was critical of the failure to invite more than a few representatives of the Romanian arts or media to Finland, despite the fact that Finnish cultural figures received continuous invitations from Romania. ${ }^{21}$

The Finnish envoy Palin was the most obvious example of a person who understood that cultural ties were inseparable from the overall relationship between Finland and Romania. Palin assumed the office of Finland's envoy to Romania in the spring of 1941. His initial impression of Romania was negative, but he would soon change his mind. From summer 1941 on, Palin - both in private conversations and in public - expressed his notion that the positions of Romania and Finland as allies or comrades-in-arms of Germany threatened by their common neighbour, the Soviet Union, were practically identical. He concluded that it would be sensible for Finland to establish as close a cooperation with Romania as possible. ${ }^{22}$

Palin's main objective was to make the Finnish government and the Ministry of Foreign Affairs understand the similarities between Finland's and Romania's geopolitical and strategic goals, but it seems that he also grasped the value of expanding and improving intercultural relationships from a wider perspective. Palin actively promoted visits by representatives of Finnish culture to Romania and vice versa, as well as other means of cultural exchange, such as translations of literature in both directions. ${ }^{23} \mathrm{He}$ also understood the importance of formal courtesy and appreciation for advancing the bilateral relationship. ${ }^{24}$ Furthermore, Palin supported various humanitarian projects, such as food and material aid between the two countries. ${ }^{25}$ All in all, it seems that he made a conscious decision in the summer of 1941: although Romania's apparent corruption and disorganisation - at least in the eyes of Palin, who shared the widespread appreciation for Northern "discipline and order" - still annoyed him ${ }^{26}$, he wanted to create a positive image of the country and introduce Finns and Romanians to each other in all aspects of life.

In cognitive psychology, it is common knowledge that the mind strives to rid its imagination of controversy: for example, if the perception of another nation is generally positive, it is easy for all elements to appear favourable even if there is no "objective" reason. This effect can also be viewed from the reverse angle: if a certain impression can be generated with respect to minor aspects, it will push the mental

21Palin to Professor V. J. Mansikka, 16 January 1943, AFLB, I E 2 b.

22Palin's annual report to Ministry of Foreign Affairs 1941-1942, AFLB, III A 2; Palin's report to Ministry of Foreign Affairs, 19 July 1941, AFMFA, 5 C 14.

23Palin to Ministry of Foreign Affairs, 12 April 1943, AFLB, I E 2.

24Palin to Professor V. J. Mansikka, 16 January 1943, AFLB, I E 2b; Palin to Ministry of Foreign Affairs, 15 March 1943, AFLB, I D 1 b.

25Palin to Ministry of Foreign Affairs, 28 January 1943, AFLB, III A 4.

26Palin's reports to Ministry of Foreign Affairs, 18 April 1941, 5 January 1942, 21 October 1942, AFLB III A 1. 
image of the central elements in the same direction. ${ }^{27}$ In retrospect, it is of course difficult to say how consciously Palin strove to convey a particular image of Romania. His reports to the Finnish Ministry of Foreign Affairs and other activities nevertheless reveal that he viewed the intensification of intercultural relations as important for Finland in order to realise Romania's value and usefulness as a partner.

Another significant player was the Finnish-Romanian Association, which commenced activities in January 1943 and continued until the summer of 1944. It says much about the general state of bilateral relations that this Finnish association was founded upon a Romanian initiative. The formal initiator was the Romanian chargé d'affaires, George Duca, but the driving force in the background was the Romanian Ministry of Foreign Affairs. At the same time, in February 1943, a Romanian-Finnish association was founded in Romania. The slightly unorthodox beginning of the Finnish-Romanian Association notwithstanding, it is evident that the organisation was an active and authoritative force from the start. As soon as the Finnish friends of Romania had been brought together in this way, they began to promote cultural cooperation between the two countries independently. Of course it was of great help that they were assisted in this by the fairly sizable monthly grant (approximately $€ 1,000$ ) the association received from the Romanian embassy. ${ }^{28}$

Many members of the Finnish-Romanian Association and its management were well-known experts from many fields of life. Eero Rydman, managing director of the Finnish Social Security Institution, was named its chairman, while other leading figures included Eino Kalima, director of the Finnish National Theatre; Rolf Nevanlinna, rector of Helsinki University; and many other high-profile representatives of the sciences, arts and public administration. The common denominator between them lay in their disinterest in kinship-based ideologies and, in many cases, an international orientation in their own respective fields, for example towards Great Britain, France and Eastern Europe. Some members, such as Nevanlinna, also had prior experience of cooperation with Romania. ${ }^{29}$

During 1943-1944, the association organised visits to Finland by Romanian artists and scientists, disseminated information on cultural life in Romania, and published articles on Romania in Finnish newspapers and magazines. A notable achievement was the publication of a general brochure on Romania in the spring of 1944. The 109-page book, titled Romania - Latinalainen saareke Kaakkois-Euroopassa

27Michael Argyle, The social psychology of everyday life (London: Routledge, 1992), 173; Kenneth J. Gergen and Mary M. Gergen, Social psychology (New York: Springer Verlag, 1986), 144-149.

28 Palin's report to Ministry of Foreign Affairs, 5 March 1943, AFLB, I E 2b; Miloiu 2005a, 413-416; Salo 2013, 17.

${ }^{29}$ Miloiu 2005a, 416; Salo 2013, 7-16. 
("Romania - Latin Enclave in Eastern Europe") was by far the most comprehensive work on Romania written in Finnish at the time. ${ }^{30}$ The identity of its author remains uncertain. It may have been written by the Romanian envoy, Georges Caranfil; another possible contributor is Yrjö Kivimies, a Finnish writer who had visited Romania in January 1944 in response to an invitation from the Romanian government; ${ }^{31}$ or possibly, it was a result of their mutual cooperation. At any rate, the book's image of Romania's history, people and society was very strongly influenced by the concept of Romanian nationalism.

In the summer of 1944, the activities of the association seem to have come to an end, as travel and other communication between Finland and Romania had become virtually impossible due to the development of the military situation.

According to the statutes of the Finnish-Romanian Association, the purpose of the organisation was to develop and deepen the friendship and understanding between the peoples of Finland and Romania and to promote educated interaction through meetings, presentations and festivities, without any interference from politics. ${ }^{32}$ The exclusion of political issues ensured that the association could also accept Romanian citizens as its members. Finnish law prohibited the membership of foreigners in politically active organisations. The formal disclaimer notwithstanding, it can be assumed with certainty that the association also endeavoured to influence "state matters", in this case the overall relationship between Finland and Romania, without ignoring the field of politics. ${ }^{33}$ This conclusion is the result of a closer look at the composition of the organisation and the time of its inception.

Almost all leaders and members of the association were high-profile representatives of sciences, arts, public administration and the like. Active media representatives also took part. The association's strong elitist trait suggests that its members had been invited purposefully and a rough distribution of work had been agreed on in advance. The association had an exceptionally broad capacity to influence various fields of culture and to lead the way by conveying a positive image of Romania towards the grassroots level of cultural life in Finland and the general populace. No evidence survives to prove that its leading figures founded the association on their own account. It seems more likely that George Duca, on behalf of the Romanian government, contacted the Finnish government presumably the Ministry of Foreign Affairs - and prepared a list of invitees

\footnotetext{
${ }^{30}$ Romania - Latinalainen saareke Kaakkois-Euroopassa (Helsinki: Suomen kirja, 1944). The closest point of comparison was 31-page Romania. Maa ja kansa (Helsinki:Tilgmann, 1935).

31 Lindgren 2000, 23; Miloiu 2005a, 418; Salo 2013, 54-56.

32 The registration form and the statutes of the Finnish-Romanian Association are the only existing documents produced by the Association itself that have been preserved and found in Finnish archives. The statutes are also printed as appences in Salo's book: Salo 2013, 66-69.

${ }^{33}$ Compare with Salo 2013, 16-18.
} 
together with Finnish officials. Without high-level approval and encouragement on the Finnish side, Duca would hardly have been able to take the initiative in the matter and win over so many renowned public figures for the association. ${ }^{34}$

The association was founded around the beginning of 1943, by which time the ultimate defeat of the axis powers in the Second World War was becoming obvious. This allows for the hypothesis that the situation at hand suggested the founding of the association to be a practicable way of preparing for disentanglement from the war. It was as yet impossible to know when and under which circumstances Finland and Romania would be able to sue for peace and to terminate their alliance with Germany, but it was almost certain that they would not be able to dictate terms from a victorious position. If each of the two countries were to cut its ties with Germany and to negotiate peace terms on its own, conditions would without doubt be very difficult. A close cooperation between them might improve the situation at least to some degree. In this context, intercultural cooperation would clearly serve a greater goal. In addition, the expansion and intensification of this cooperation were formally non-political activities and would therefore not attract unwanted attention - particularly from the Germans, who already doubted the loyalty of both Finland and Romania as allies in the war.

Romania's image in the Finnish media, that is, in newspapers and magazines, was closely tied to the activities of the Finnish-Romanian Association. Before 1943, very few of the Romania-related articles published in Finland took notice of cultural matters. Instead, they focused on war news, geopolitics, the brotherhoodin-arms between Finland and Romania, and their common goals. ${ }^{35}$ Even features of this type were scarce, apart from brief telegraphs. The largest feature was a special issue on Romania published by the military magazine Suomen Sotilasin spring 1942, which shed a very positive light on the Romanian army and its feats in the war. ${ }^{36}$

When the Finnish-Romanian Association, in cooperation with its Romanian partners, began to organise visits by Romanian artists and scientists to Finland, the culture of their homeland was clearly given more attention by the Finnish press. During 1943-1944, nationwide papers such as Helsingin Sanomat, Uusi Suomi and Suomen Sosialidemokraatti published an average of 1-2 articles per month that mentioned, albeit in brief, the association's activities or visiting representatives of

\footnotetext{
34 Compare with Salo 2013, 16-18.

35 See. for instance, Helsingin Sanomat, 15 February 1942, "Romanian asema", in Helsingin Sanomat, 8 April 1942.

${ }^{36}$ Suomen Sotilas 8/1942. The special issue contained, among others, the following articles/headlines: "A brave brother of arms" (Romania), "A king loved by His people" (King Michael), "A skillful leader of the state" (Marshal Ion Antonescu), "Two comrades sharing the same destiny" (Finland and Romania), "Splendid military commanders" (Marshal C. G. E. Mannerheim and Marshal Ion Antonescu).
} 
Romanian culture. ${ }^{37}$ Reviews of Romanian artists' performances were positive throughout. ${ }^{38}$ Regarding the frequency and tone of Romania-related articles, there was no evident difference between the three newspapers mentioned above. Usually the work of the Finnish-Romanian Association was not commented on directly, but indirect references - in connection with appearances by major Romanian artists were made from a positive angle. ${ }^{39}$ The discontinuation of the association in 1944 was reflected in the cessation of visits from Romania to Finland and of news on the two countries' intercultural relations in the press.

Although press coverage of Romanian culture increased slightly in 1943-1944, the leading position of main competitor Hungary remained uncontested. In spring 1943, the Hungarian Legation in Helsinki and the Finnish-Hungarian Society launched a countercampaign in order to challenge the activation of Romania and the Finnish-Romanian Association and to preserve the strong sympathies held by Finns towards Hungary. ${ }^{40}$ No systematic research exists on Finnish press coverage of Hungary, but the documentation available reveals that throughout the war, Hungary was awarded much more column space and positive attention than Romania.41 The same is true for the wartime schoolbooks that shaped the worldview of children and teenagers. ${ }^{42}$

\section{Conclusions}

The stance of the Finnish government and Ministry of Foreign Affairs was hesitant all the time from the outbreak of the WWII to 1944. However, it can be seen that several Finnish parties were interested in the promotion of cultural relations with Romania. As such, this area formed an integral and relatively important part of bilateral relations. On the other hand, Finland's close cultural ties with Hungary posed a great challenge to the advancement of Finnish-Romanian relations. The course of the war also had an effect on how or whether Finnish efforts to promote cultural relations with Romania could succeed.

\footnotetext{
37 A press survey of 1943-1944 has been made by Salo 2013, 35-54.

38 See, for instance, Uusi Suomi, 11 May 1943; Suomen Sosialidemokraatti, 18 September 1943; Helsingin Sanomat, 14 January 1944.

${ }^{39}$ Suomen Sosialidemokraatti, 19 September 1943; Uusi Suomi, 4 November 1943; Helsingin Sanomat, 10 January 1944.

40 Halmesvirta 2010, 165-166.

41For instance, in Suomen Sotilas practically every number between summer 1941 and summer 1944 contained at least one newspiece or article on Hungary while news about Romania were only published occasionally (excluding the above-mentioned special issue dedicated to Romania, Suomen Sotilas 8/1942).

42 See, for instance, Alma Hakalehto \& Alfred Salmela, Isänmaa ja maailma.Kansakoulun maantieto (Porvoo: WSOY, 1944), 126-131; Oskari Mantere \& Gunnar Sarva, Keskikoulun yleinen historia II (Porvoo: WSOY, 1944), 252-254, 327, 341.
} 
Finland's leading media portrayed the activities of the Finnish-Romanian Association in a positive light and dedicated a fair amount of column space to visits and performances by representatives of Romanian culture in Finland. However, during the war there was no elementary change in the basic tendency to focus positive attention on Hungary, despite efforts by Palin and the Finnish-Romanian Association to encourage a more balanced representation of the respective points of view in the coverage of Romania and Hungary.

\section{References:}

\section{A. Primary sources}

Archives of the Finnish Legation in Bucharest (AFLB)

I E - III A

Archives of the Finnish Ministry of Foreign Affairs (AFMFA)

5 C 14

Hakalehto,Alma \& Salmela, Alfred.Isänmaa ja maailma. Kansakoulun

maantieto. Porvoo: WSOY, 1944.

Helsingin Sanomat, 15 February 1942

Helsingin Sanomat, 8 April 1942

Helsingin Sanomat, 10 January 1944

Helsingin Sanomat, 14 January 1944

Mantere, Oskari \& Sarva, Gunnar.Keskikoulun yleinen historia II. Porvoo: WSOY, 1944.

Ministry of Education and Culture: Cultural Agreements. Http://www.minedu.fi/OPM/Kansainvaeliset_asiat/kulttuurisopimukset_ja_ohjelmat/?1 ang=en (accessed 5 August 2014).

Romania - Latinalainen saareke Kaakkois-Euroopassa. Helsinki: Suomen kirja, 1944.

Romania. Maa ja kansa. Helsinki: Tilgmann, 1935.

Suomen Sosialidemokraatti, 18 September 1943

Suomen Sosialidemokraatti, 19 September 1943

Suomen Sotilas, 8/1942

Uusi Suomi, 11 May 1943

Uusi Suomi, 4 November 1943

\section{B. Research literature and articles}

Alenius, Kari. "An Excellent Friend Afflicted with Internal Difficulties": The Image of Romania Conveyed by the Finnish Embassy in Bucharest, 1939-1945.' In Valahian Journal of Historical Studies, 16/2011, 21-33.

Argyle, Michael.The social psychology of everyday life. London: Routledge, 1992.

Gergen, Kenneth J. and Gergen, Mary M. Social psychology. New York: Springer Verlag, 1986.

Halmesvirta, Anssi. Rakkaat heimoveljet: Unkari ja Suomi 1920-1945.

Jyväskylä: Historietti Oy, 2010. 
Kukkonen, Anu. Pustalla ei ole polkua. Unkari-kuva äidinkielen oppikirjoissa (unpublished M.A. thesis). Jyväskylä: Jyväskylän yliopisto, 2003.

Lindgren, Lauri. 'Suomalaisten ja romanialaisten kontaktit menneinä

aikoina'. In 80 vuotta Suomen ja Romanian välisiä diplomaattisuhteita. Helsinki: Embassy of Romania, National Archives of Finland \& Finnish-Romanian Friendship Association 2000.

Maasalo, Erkki. Sir Henrik saa tehtäzän. Henrik Ramsayn ulkoasiainministerikausi 1943-1944. Espoo: Fenix-Kustannus Oy, 2004.

Miloiu, Silviu. 'Cultures at war: The cultural relations between Romania and Finland during the Second World War.' In Anuarul Institutului de Istorie "A. D. Xenopol", t. XLII, 2005, 409-421.

Miloiu, Silviu. 'Mobilizing the European idea at Europe's eastern frontier. The war propaganda of Romania and Finland as recorded in their bilateral relationship.' In Valahian Journal of Historical Studies, 3-4/2005, 67-75.

Miloiu, Silviu. 'Finnish views and political attitudes concerning the

Romanian-Hungarian clash over Transylvania (1941-1942).' In Studia Universitatis BabeşBolyai, Studia Europaea, LI, 1, 2006, 105-119.

Miloiu, Silviu. 'An untold story: The Romanian-Finnish diplomatic bonds (1923-1939).' In Valahian Journal of Historical Studies, 7-8/2007, 93-110.

Miloiu, Silviu. 'From "allies without alliance" to concerted action: Romania and Finland in the aftermath of the Operation Barbarossa (1941).' In Revista Română de Studii Baltice şi Nordice, Vol. 2, Nr. 2 (2010), 249-284.

Nevakivi, Jukka. Ulkoasiainhallinnon historia 1918-1956. Helsinki:

Ulkoasiainministeriö 1988.

Rintala, Otto. '"Erillissodan maat" Suomi ja Romania toisessa

maailmansodassa Suomen Bukarestin-lähetystön toiminnan näkökulmasta.' In Ajankohta 2007. Poliittisen historian vuosikirja. Toim. Klaus Lindgren. Helsinki: Helsingin yliopisto \& Turun yliopisto, 2007, 214-241.

Salo, Erkki. Kulttuurikomennus. Suomalais-romanialainen yhdistys 1943-1944. Helsinki: Albion 2013. 